\title{
Pengaruh Faktor Bermukim Masyarakat Terhadap Pola Persebaran Permukiman Di KaWASAN RAWAN BENCANA LONGSOR KABUPATEN MAGETAN
}

\author{
Adryan Aji Saiful Bachry, Ana Hardiana, Rufia Andisetyana Putri \\ Program Studi Perencanaan Wilayah dan Kota, \\ Fakultas Teknik \\ Universitas Sebelas Maret, Surakarta \\ email: aji.adryan@gmail.com
}

\begin{abstract}
Housing and settlements is fundamental human need to do daily activities for the survival of mankind. The community in determining the location of settlements have basic considerations that affect them in choosing a location for a settlement. The basic consideration is composed of several factors, including accessibility, environment, job opportunities, level of service, in addition to psychological factors, socioeconomic factors and historical cultural factors. Basically the location of settlements or housing are not allowed on the mountain slopes are potentially landslide disaster. Landslide that is threatening the survival of human beings who lived in the area. The danger of a disaster is a natural or artificial phenomena which have the potential to threaten human life, loss of property and damage to the environment. The area of the slopes of Mount Lawu which has a dense contour and topography make settlement patterns that are located in the area most are clumped as well as the distance between one another with their distance. There are several factors that affect the formation of settlement patterns, namely economic, cultural, institutional and customs. The issue of this study is to examine how the influence factors of settlement in the area of landslide-prone Magetan against pattern of settlement that is formed in the area. This study discusses the characteristics of the factor pattern of distribution in the community, the establishment of settlements and the influence factors of settlement against the spread pattern of settlement in the area of the landslide-prone Magetan by using multiple linear regression analysis. The community has its own considerations against the selection of the location of the settlement which made slopes be settled and be against the formation of settlement patterns in the Poncol Districts and Plaosan Districts which located on the slopes of Mount Lawu. Of research results obtained in the area of community based factors prone to landslide has no influence on the pattern of the spread of settlements that was formed in the area.
\end{abstract}

Keywords: landslides, mountains, settlement, settlement patterns, the spread of settlements

\section{PENDAHULUAN}

Perumahan dan permukiman merupakan kebutuhan mendasar manusia untuk melakukan kegiatan sehari-hari demi kelangsungan hidup manusia. Perumahan dan permukiman mempunyai fungsi dan peranan yang penting dalam kehidupan manusia, perumahan merupakan pencerminan dari jati diri pribadi manusia. Permukiman merupakan tempat hidup manusia dan melakukan berbagai macam kegiatan yang di dalamnya tersedia sarana dan prasarana penunjang dan lapangan pekerjaan untuk kegiatan sehari-hari masyaraakt yang tinggal di kawasan permukiman tersebut hal tersebut dapat mempengaruhi masyarakat dalam membentuk kawasan permukiman dengan bentuk yang berbeda-beda.

Pola permukiman memiliki variasi pola dari yang sangat jarang hingga sangat padat, mengelompok, teratur dan tidak teratur. Kawasan permukiman akan banyak terdapat pada kawasan yang memiliki tingkat penunjang hidup yang tinggi, misalnya pada kawasan yang subur untuk menguntungkan pertanian. Menurut Dwi Ari dan Antariksa (2005:79) pola permukiman membicarakan sifat persebaran permukiman dengan kata lain pola permukiman secara umum 
merupakan susunan sifat berbeda dari hubungan faktor-faktor yang menentukan persebaran permukiman.

Masyarakat dalam menentukan lokasi permukiman memiliki dasar pertimbangan yang mempengaruhi mereka dalam memilih lokasi untuk bermukim. Dasar pertimbangan tersebut terdiri dari beberapa faktor menurut Drabkin dalam Paruntung (2004) beberapa faktor tersebut adalah aksesibilitas, lingkungan, peluang kerja, tingkat pelayanan. Selain itu manusia memilih tempat tinggal untuk melakukan kegiatan setiap individunya memiliki perbedaan masing-masing terdapat beberapa alasan dalam pemilihan lokasi dalam bermukim antara lain faktor psikologis, faktor sosial ekonomi dan faktor kultural historis.

Fenomena yang terjadi berada pada kawasan lereng Gunung Lawu yang berada di Kabupaten Magetan khususnya berada di Kecamatan Poncol dan Kecamatan Plaosan. Sesuai dengan uraian RTRW Kabupaten Magetan Kecamatan Poncol kawasan rawan bencana terletak pada Desa Genilangit dan Desa Gonggang sedangkan pada Kecamatan Plaosan berada pada Desa Pacalan, Ngancar dan Sarangan yang semua kecamatan berada di lereng Gunung Lawu jenis tanah yang berada pada kawasan longsor di Kabupaten Magetan adalah jenis andosol dan latosol yang mudah longsor apabila penggunaan lahan yang tidak sesuai dan curah hujan yang tinggi sehingga masyarakat yang tinggal di kawasan tersebut harus berhati-hati apabila curah hujan di kawasan tersebut tinggi.

Pada dasarnya letak permukiman maupun perumahan tidak diperbolehkan berada pada daerah lereng gunung yang berpotensi terjadi bencana longsor, namun masyarakat memiliki pertimbanganpertimbangan sendiri terhadap pemilihan lokasi bermukim yang menjadikan lereng gunung menjadi pilihan bermukim. Penelitian ini bermaksud untuk mengetahui pengaruh faktor-faktor bermukim masyarakat terhadap terbentuknya pola permukiman di Kecamatan Poncol dan Plaosan
Kabupaten Magetan yang berada di lereng Gunung Lawu.

Tujuan peneletian ini untuk mengetahui faktor-faktor bermukim masyarakat berdasarkan masyarakat, karakteristik pola persebaran permukiman, serta pengaruh faktor bermukim masyarakat terhadap pola persebaran permukiman di kawasan rawan bencana longsor Kabupaten Magetan.

Dari hasil penelitian akan digunakan untuk mengetahui faktor yang mempengaruhi pola persebaran permukiman sehingga dapat digunakan sebagai acuan regulasi untuk membuat kawasan permukiman baru yang aman bagi masyarakat yang sesuai dengan eksisting di kawasan rawan bencana longsor.

\section{METODE}

\section{A. Ruang Lingkup}

Wilayah yang akan di teliti dalam penelitian ini adalah kawasan rawan bencana longsor di Kabupaten Magetan yang sesuai dengan pemetaan RTRW Kabupaten Magetan Tahun 20122032 yang secara administratif meliputi :

1. Kecamatan Panekan yang meliputi Desa Jabung.

2. Kecamatan Plaosan yang meliputi Desa Pacalan, Desa Sarangan, dan Desa Dadi.

3. Kecamatan Poncol yang meliputi Desa Genilangit dan Desa Gonggang.

Kawasan yang menjadi daerah rawan bencana tanah longsor adalah Kecamatan Plaosan dan Kecamatan Poncol sesuai dengan RTRW Kabupetn Magetan 20122032 yang memiliki kemiringan lahan antara 15\%-40\% dan memiliki curah hujan dengan 1.551 $\mathrm{mm}$ per tahun dan jenis tanah andosol dan latosol. Kecamatan Plaosan dan Kecamatan Poncol merupakan kawasan rawan bencana tanah longsor tingkat tinggi yang berada di Kabupaten Magetan yang 
dapat dilihat dari frekuensi terjadinya bersifat tahunan.

B. Metode Analisis

Dalam penelitian ini akan membahas bagaimana pengaruh faktor bermukim masyarakat di kawasan rawan bencana longsor terhadap pola permukiman yang terbentuk di kawasan tersebut.

1. Identifikasi faktor bermukim masyarakat.

Teknik analisis yang digunakan dalam menganalisis sasaran di atas dengan menggunakan teknik pembobotan atau skoring. Dalam pembobotan atau skoring digunakan skala Likert yang merupakan skala untuk mengukur sikap, pendapat, dan persepsi seseorang atau sekelompok orang terhadap faktor-faktor yang berpengaruh yang sebelumnya sudah ditentukan oleh peneliti (Sugiyono, 2009). Identifikasi faktor bermukim berdasarkan standart atau teori yang sudah ditentukan sebelumnya yaitu seperti manajemen bencana, fisik lingkungan, sarana prasarana, aksesibilitas dan lainlain.

2. Identifikasi pola persebaran permukiman.

Teknik analisis yang digunakan dalam menganalisis sasaran di atas akan menggunakan teknik analisis tetangga terdekat yang memerlukan data jarak antara satu permukiman dengan permukiman yang lain. Teknik analisis ini dipakai karena dalam penelitian ini ingin mengetahui pola persebaran permukiman yang sesuai dengan acuan teori yang sudah dilakukan pendalaman sebelumnya. Identifikasi pola persebaran permukiman ini dilakukan untuk mengetahui pola-pola persebaran permukiman yang terjadi di kawasan rawan bencana longsor yang sesuai dengan topik penelitian.

3. Analisis pengaruh faktor bermukim terhadap pola persebaran permukiman. Akan dilakukan analisis regresi berganda yang menghubungkan antara variabel terikat yaitu variabel pola persebaran permukiman dengan variabel bebas yaitu variabel faktor bermukim masyarakat di kawasan rawan bencana longsor. Dengan tujuan untuk mengestimasi atau memprediksi nilai variabel terikat berdasarkan nilai variabel bebas.

\section{HASIL DAN PEMBAHASAN}

A. Identifikasi Faktor Bermukim Masyarakat.

Analisis faktor-faktor bermukim masyarakat terkait peluang pekerjaan diperoleh hasil sebagian besar adalah sangat sesuai karena lokasi pekerjaan berada pada kawasan permukiman, faktor aksesibilitas sebagian besar tidak sesuai karena akses angkutan umum yang tidak tersedia dan akses ke sarana pendukung yang jauh, faktor prasarana diperoleh hasil sebagian besar sangat sesuai karena jaringan-jaringan pendukung yang memadai, faktor manajemen bencana diperoleh hasil sesuai untuk semua zona, faktor lingkungan diperoleh hasil sangat sesuai di semua zona karena kualitas air, udara dan kebisingan yang tidak tercemar, faktor topografi memiliki hasil yang bervariasi dikarenakan zona kawasan permukiman berada pada kawasan pegunungan dengan kontur yang bermacam-macam, dan untuk faktor status hukum sebagian besar diperoleh hasil sangat sesuai karena kepemilikan lahan yang sudah bersertifikat dan sesuai dengan regulasi terkait yang dapat dilihat pada lampiran 1 tabel analisis skoring. 
B. Identifikasi Pola Persebaran Permukiman.

Sebagian besar pola persebaran permukiman di kawasan rawan bencana longsor secara menyebar sebesar $91 \%$ atau 29 zona sedangkan untuk pola persebaran secara menyebar sebesar $9 \%$ atau 3 zona dapat dilihat pada lampiran 1 tabel analisis skoring dan lampiran 3 gambar peta zona kawasan permukiman.

C. Analisis Pengaruh Faktor Bermukim Terhadap Pola Persebaran Permukiman.

Analisis pengaruh faktor bermukim masyarakat terhadap pola persebaran permukiman menggunakan teknik analisis regresi linear berganda dengan variabel terikat pola persebaran permukiman dan variabel bebas adalah faktor bermukim yang terdiri dari peluang pekerjaan, aksesibilitas, prasarana, manajemen bencana, lingkungan, topografi, dan status hukum. Dari analisis pengaruh diperoleh hasil faktor bermukim tidak berpengaruh terhadap pola persebaran permukiman di kawasan rawan bencana longsor Kabupaten Magetan. Masyarakat yang tinggal di kawasan tersebut sudah bermukim secara turun temurun sehingga faktor-faktor bermukim tidak berpengaruh karena sarana prasarana yang mendukung kegiatan masyarakat sudah dapat membantu. Kawasan rawan bencana longsor Kabupaten Magetan secara garis besar dapat memenuhi kebutuhan masyarakat untuk bertempat tinggal di kawasan tersebut terkait sarana prasarana penunjang, selain itu ketersediaan lapangan pekerjaan bagi masyarakat yang berada di kawasan tersebut telah terpenuhi sehingga masyarakat dapat melakukan kegiatan untuk menunjang hidup. Hasil analisis yang diperoleh berbanding terbalik dengan teori yang menyebutkan faktor-faktor bermukim merupakan faktor yang berpengaruh terhadap terjadinya pola persebaran permukiman di suatu kawasan hasil analisis dapat dilihat pada lampiran 2 tabel analisis regresi berganda.

\section{KESIMPULAN}

Berdasarkan hasil analisis pengaruh faktor bermukim masyarakat terhadap pola persebaran permukiman dapat dilihat bahwa faktor bermukim masyarakat tidak memiliki pengaruh terhadap pola persebaran permukiman. Hal tersebut dikarenakan faktor-faktor di luar dari faktor yang menjadi tolok ukur di dalam penelitian ini. Hasil penelitian ini di harapkan menjadi acuan penelitian selanjutnya terkait faktor-faktor bermukim masyarakat yang berpengaruh terhadap pola persebaran permukiman secara mendalam.

\section{REFERENSI}

BAPPEDA Kabupaten Magetan

Dwi Ari, I, R. \& Antariksa, 2005. Studi Karakteristik Pola Permukiman di Kecamatan Labang, Madura. Jurnal ASPI Volume 4 Nomor 2, April 2005, hlm. 78-93

Paruntung, M. 2004. "Faktor-faktor Yang Mempengaruhi Pemilihan Lokasi Perumahan Perumnas IV Padang Bulan Kota Jayapura”. Tesis Teknik Pada UNDIP Semarang.

Peraturan Menteri No. 22 Tahun 2007 tentang Kawasan Rawan Bencana longsor

Peraturan Daerah Kabupaten Magetan Nomor 15 Tahun 2013 Tentang Rencana Tata Ruang Wilayah Kabupaten Magetan Tahun 20132032

Sugiyono, 2009. Statistika Untuk Penelitian. Bandung : Alfabeta 
LAMPIRAN

Lampiran 1. Tabel Skoring Faktor Bermukim dan Pola Persebaran Permukiman

\begin{tabular}{|c|c|c|c|c|c|c|c|c|}
\hline \multirow[b]{2}{*}{ Zona } & \multicolumn{7}{|c|}{ Faktor Bermukim Masyarakat } & \multirow{2}{*}{$\begin{array}{c}\text { Pola } \\
\text { Persebara } \\
\text { n } \\
\text { Permukim } \\
\text { an } \\
\end{array}$} \\
\hline & $\begin{array}{c}\text { Peluang } \\
\text { Pekerjaan }\end{array}$ & $\begin{array}{c}\text { Aksesibilit } \\
\text { as }\end{array}$ & $\begin{array}{c}\text { Prasaran } \\
\mathbf{a}\end{array}$ & $\begin{array}{c}\text { Manaje } \\
\text { men } \\
\text { Bencana }\end{array}$ & $\begin{array}{l}\text { Lingk } \\
\text { ungan }\end{array}$ & Topografi & Status Hukum & \\
\hline 1 & $\begin{array}{c}3 \\
\text { (sangat } \\
\text { sesuai }\end{array}$ & $\begin{array}{c}1 \\
\text { (Tidak } \\
\text { sesuai) }\end{array}$ & $\begin{array}{c}3 \\
\text { (Sangat } \\
\text { sesuai) }\end{array}$ & $\begin{array}{c}2 \\
\text { (Sesuai) }\end{array}$ & $\begin{array}{c}3 \\
\text { (Sangat } \\
\text { sesuai) }\end{array}$ & $\begin{array}{c}3 \\
\text { (Sangat sesuai) }\end{array}$ & $\begin{array}{c}3 \\
\text { (sangat sesuai) }\end{array}$ & $\begin{array}{c}2 \\
\text { (menyeb } \\
\text { ar) }\end{array}$ \\
\hline 2 & $\begin{array}{c}3 \\
\text { (sangat } \\
\text { sesuai }\end{array}$ & $\begin{array}{c}1 \\
\text { (Tidak } \\
\text { sesuai) } \\
\end{array}$ & $\begin{array}{c}3 \\
\text { (Sangat } \\
\text { sesuai) } \\
\end{array}$ & $\begin{array}{c}2 \\
\text { (Sesuai) }\end{array}$ & $\begin{array}{c}3 \\
\text { (Sangat } \\
\text { sesuai) }\end{array}$ & $\begin{array}{c}3 \\
\text { (Sangat sesuai) }\end{array}$ & $\begin{array}{c}3 \\
\text { (sangat sesuai) }\end{array}$ & $\begin{array}{c}2 \\
\text { (menyeb } \\
\text { ar) }\end{array}$ \\
\hline 3 & $\begin{array}{c}3 \\
\text { (sangat } \\
\text { sesuai }\end{array}$ & $\begin{array}{c}1 \\
\text { (Tidak } \\
\text { sesuai) }\end{array}$ & $\begin{array}{c}3 \\
\text { (Sangat } \\
\text { sesuai) }\end{array}$ & $\begin{array}{c}2 \\
\text { (Sesuai) }\end{array}$ & $\begin{array}{c}3 \\
\text { (Sangat } \\
\text { sesuai) }\end{array}$ & $\begin{array}{c}3 \\
\text { (Sangat sesuai) }\end{array}$ & $\begin{array}{c}3 \\
\text { (sangat sesuai) }\end{array}$ & $\begin{array}{c}2 \\
\text { (menyeb } \\
\text { ar) }\end{array}$ \\
\hline 4 & $\begin{array}{c}3 \\
\text { (sangat } \\
\text { sesuai } \\
\end{array}$ & $\begin{array}{c}1 \\
\text { (Tidak } \\
\text { sesuai) } \\
\end{array}$ & $\begin{array}{c}3 \\
\text { (Sangat } \\
\text { sesuai) } \\
\end{array}$ & $\begin{array}{c}2 \\
\text { (Sesuai) }\end{array}$ & $\begin{array}{c}3 \\
\text { (Sangat } \\
\text { sesuai) } \\
\end{array}$ & $\begin{array}{c}3 \\
\text { (Sangat sesuai) }\end{array}$ & $\begin{array}{c}3 \\
\text { (sangat sesuai) }\end{array}$ & $\begin{array}{c}2 \\
\text { (menyeb } \\
\text { ar) } \\
\end{array}$ \\
\hline 5 & $\begin{array}{c}3 \\
\text { (sangat } \\
\text { sesuai }\end{array}$ & $\begin{array}{c}1 \\
\text { (Tidak } \\
\text { sesuai) }\end{array}$ & $\begin{array}{c}2 \\
\text { (sesuai) }\end{array}$ & $\begin{array}{c}2 \\
\text { (Sesuai) }\end{array}$ & $\begin{array}{c}3 \\
\text { (Sangat } \\
\text { sesuai) }\end{array}$ & $\begin{array}{c}2 \\
\text { (Sesuai) }\end{array}$ & $\begin{array}{c}3 \\
\text { (sangat sesuai) }\end{array}$ & $\begin{array}{c}2 \\
\text { (menyeb } \\
\text { ar) }\end{array}$ \\
\hline 6 & $\begin{array}{c}3 \\
\text { (sangat } \\
\text { sesuai } \\
\end{array}$ & $\begin{array}{c}1 \\
\text { (Tidak } \\
\text { sesuai) } \\
\end{array}$ & $\begin{array}{c}3 \\
\text { (Sangat } \\
\text { sesuai) } \\
\end{array}$ & $\begin{array}{c}2 \\
\text { (Sesuai) }\end{array}$ & $\begin{array}{c}3 \\
\text { (Sangat } \\
\text { sesuai) } \\
\end{array}$ & $\begin{array}{c}2 \\
\text { (Sesuai) }\end{array}$ & $\begin{array}{c}3 \\
\text { (sangat sesuai) }\end{array}$ & $\begin{array}{c}2 \\
\text { (menyeb } \\
\text { ar) }\end{array}$ \\
\hline 7 & $\begin{array}{c}3 \\
\text { (sangat } \\
\text { sesuai }\end{array}$ & $\begin{array}{c}1 \\
\text { (Tidak } \\
\text { sesuai) }\end{array}$ & $\begin{array}{c}2 \\
\text { (sesuai) }\end{array}$ & $\begin{array}{c}2 \\
\text { (Sesuai) }\end{array}$ & $\begin{array}{c}3 \\
\text { (Sangat } \\
\text { sesuai) }\end{array}$ & $\begin{array}{c}2 \\
\text { (Sesuai) }\end{array}$ & $\begin{array}{c}3 \\
\text { (sangat sesuai) }\end{array}$ & $\begin{array}{c}2 \\
\text { (menyeb } \\
\text { ar) }\end{array}$ \\
\hline 8 & $\begin{array}{c}3 \\
\text { (sangat } \\
\text { sesuai }\end{array}$ & $\begin{array}{c}1 \\
\text { (Tidak } \\
\text { sesuai) } \\
\end{array}$ & $\begin{array}{c}3 \\
\text { (Sangat } \\
\text { sesuai) } \\
\end{array}$ & $\begin{array}{c}2 \\
\text { (Sesuai) }\end{array}$ & $\begin{array}{c}3 \\
\text { (Sangat } \\
\text { sesuai) } \\
\end{array}$ & $\begin{array}{c}2 \\
\text { (Sesuai) }\end{array}$ & $\begin{array}{c}3 \\
\text { (sangat sesuai) }\end{array}$ & $\begin{array}{c}2 \\
\text { (menyeb } \\
\text { ar) }\end{array}$ \\
\hline 9 & $\begin{array}{c}3 \\
\text { (sangat } \\
\text { sesuai }\end{array}$ & $\begin{array}{c}1 \\
\text { (Tidak } \\
\text { sesuai) }\end{array}$ & $\begin{array}{c}3 \\
\text { (Sangat } \\
\text { sesuai) } \\
\end{array}$ & $\begin{array}{c}3 \\
\text { (Sangat } \\
\text { sesuai) } \\
\end{array}$ & $\begin{array}{c}3 \\
\text { (Sangat } \\
\text { sesuai) }\end{array}$ & $\begin{array}{c}2 \\
\text { (Sesuai) }\end{array}$ & $\begin{array}{c}3 \\
\text { (sangat sesuai) }\end{array}$ & $\begin{array}{c}2 \\
\text { (menyeb } \\
\text { ar) }\end{array}$ \\
\hline 10 & $\begin{array}{c}3 \\
\text { (sangat } \\
\text { sesuai }\end{array}$ & $\begin{array}{c}1 \\
\text { (Tidak } \\
\text { sesuai) }\end{array}$ & $\begin{array}{c}3 \\
\text { (Sangat } \\
\text { sesuai) } \\
\end{array}$ & $\begin{array}{c}3 \\
\text { (Sangat } \\
\text { sesuai) } \\
\end{array}$ & $\begin{array}{c}3 \\
\text { (Sangat } \\
\text { sesuai) } \\
\end{array}$ & $\begin{array}{c}2 \\
\text { (Sesuai) }\end{array}$ & $\begin{array}{c}3 \\
\text { (sangat sesuai) }\end{array}$ & $\begin{array}{c}2 \\
\text { (menyeb } \\
\text { ar) }\end{array}$ \\
\hline 11 & $\begin{array}{c}3 \\
\text { (sangat } \\
\text { sesuai }\end{array}$ & $\begin{array}{c}1 \\
\text { (Tidak } \\
\text { sesuai) } \\
\end{array}$ & $\begin{array}{c}3 \\
\text { (Sangat } \\
\text { sesuai) }\end{array}$ & $\begin{array}{c}3 \\
\text { (Sangat } \\
\text { sesuai) }\end{array}$ & $\begin{array}{c}3 \\
\text { (Sangat } \\
\text { sesuai) } \\
\end{array}$ & $\begin{array}{c}2 \\
\text { (Sesuai) }\end{array}$ & $\begin{array}{c}3 \\
\text { (sangat sesuai) }\end{array}$ & $\begin{array}{c}2 \\
\text { (menyeb } \\
\text { ar) }\end{array}$ \\
\hline 12 & $\begin{array}{c}3 \\
\text { (sangat } \\
\text { sesuai }\end{array}$ & $\begin{array}{c}1 \\
\text { (Tidak } \\
\text { sesuai) }\end{array}$ & $\begin{array}{c}3 \\
\text { (Sangat } \\
\text { sesuai) }\end{array}$ & $\begin{array}{c}3 \\
\text { (Sangat } \\
\text { sesuai) }\end{array}$ & $\begin{array}{c}3 \\
\text { (Sangat } \\
\text { sesuai) }\end{array}$ & $\begin{array}{c}2 \\
\text { (Sesuai) }\end{array}$ & $\begin{array}{c}3 \\
\text { (sangat sesuai) }\end{array}$ & $\begin{array}{c}2 \\
\text { (menyeb } \\
\text { ar) }\end{array}$ \\
\hline 13 & $\begin{array}{c}3 \\
\text { (sangat } \\
\text { sesuai }\end{array}$ & $\begin{array}{c}1 \\
\text { (Tidak } \\
\text { sesuai) } \\
\end{array}$ & $\begin{array}{c}3 \\
\text { (Sangat } \\
\text { sesuai) }\end{array}$ & $\begin{array}{c}3 \\
\text { (Sangat } \\
\text { sesuai) }\end{array}$ & $\begin{array}{c}3 \\
\text { (Sangat } \\
\text { sesuai) } \\
\end{array}$ & $\begin{array}{c}2 \\
\text { (Sesuai) }\end{array}$ & $\begin{array}{c}2 \\
\text { (sesuai) }\end{array}$ & $\begin{array}{c}2 \\
\text { (menyeb } \\
\text { ar) }\end{array}$ \\
\hline 14 & $\begin{array}{c}3 \\
\text { (sangat } \\
\text { sesuai } \\
\end{array}$ & $\begin{array}{c}1 \\
\text { (Tidak } \\
\text { sesuai) }\end{array}$ & $\begin{array}{c}3 \\
\text { (Sangat } \\
\text { sesuai) } \\
\end{array}$ & $\begin{array}{c}3 \\
\text { (Sangat } \\
\text { sesuai) } \\
\end{array}$ & $\begin{array}{c}3 \\
\text { (Sangat } \\
\text { sesuai) } \\
\end{array}$ & $\begin{array}{c}2 \\
\text { (Sesuai) }\end{array}$ & $\begin{array}{c}3 \\
\text { (sangat sesuai) }\end{array}$ & $\begin{array}{c}2 \\
\text { (menyeb } \\
\text { ar) }\end{array}$ \\
\hline 15 & $\begin{array}{c}2 \\
\text { (sesuai) }\end{array}$ & $\begin{array}{c}1 \\
\text { (Tidak } \\
\text { sesuai) } \\
\end{array}$ & $\begin{array}{c}3 \\
\text { (Sangat } \\
\text { sesuai) }\end{array}$ & $\begin{array}{c}3 \\
\text { (Sangat } \\
\text { sesuai) }\end{array}$ & $\begin{array}{c}3 \\
\text { (Sangat } \\
\text { sesuai) }\end{array}$ & $\begin{array}{c}1 \\
\text { (Tidak sesuai) }\end{array}$ & $\begin{array}{c}3 \\
\text { (sangat sesuai) }\end{array}$ & $\begin{array}{c}2 \\
\text { (menyeb } \\
\text { ar) }\end{array}$ \\
\hline 16 & $\begin{array}{c}3 \\
\text { (sangat } \\
\text { sesuai }\end{array}$ & $\begin{array}{c}1 \\
\text { (Tidak } \\
\text { sesuai) } \\
\end{array}$ & $\begin{array}{c}3 \\
\text { (Sangat } \\
\text { sesuai) }\end{array}$ & $\begin{array}{c}3 \\
\text { (Sangat } \\
\text { sesuai) } \\
\end{array}$ & $\begin{array}{c}3 \\
\text { (Sangat } \\
\text { sesuai) }\end{array}$ & $\begin{array}{c}1 \\
\text { (Tidak sesuai) }\end{array}$ & $\begin{array}{c}3 \\
\text { (sangat sesuai) }\end{array}$ & $\begin{array}{c}2 \\
\text { (menyeb } \\
\text { ar) }\end{array}$ \\
\hline 17 & $\begin{array}{c}3 \\
\text { (sangat } \\
\text { sesuai }\end{array}$ & $\begin{array}{c}1 \\
\text { (Tidak } \\
\text { sesuai) }\end{array}$ & $\begin{array}{c}3 \\
\text { (Sangat } \\
\text { sesuai) }\end{array}$ & $\begin{array}{c}3 \\
\text { (Sangat } \\
\text { sesuai) } \\
\end{array}$ & $\begin{array}{c}3 \\
\text { (Sangat } \\
\text { sesuai) }\end{array}$ & $\begin{array}{c}1 \\
\text { (Tidak sesuai) }\end{array}$ & $\begin{array}{c}3 \\
\text { (sangat sesuai) }\end{array}$ & $\begin{array}{c}2 \\
\text { (menyeb } \\
\text { ar) }\end{array}$ \\
\hline 18 & $\begin{array}{c}3 \\
\text { (sangat } \\
\text { sesuai } \\
\end{array}$ & $\begin{array}{c}1 \\
\text { (Tidak } \\
\text { sesuai) } \\
\end{array}$ & $\begin{array}{c}3 \\
\text { (Sangat } \\
\text { sesuai) } \\
\end{array}$ & $\begin{array}{c}3 \\
\text { (Sangat } \\
\text { sesuai) } \\
\end{array}$ & $\begin{array}{c}3 \\
\text { (Sangat } \\
\text { sesuai) } \\
\end{array}$ & $\begin{array}{c}1 \\
\text { (Tidak sesuai) }\end{array}$ & $\begin{array}{c}3 \\
\text { (sangat sesuai) }\end{array}$ & $\begin{array}{c}2 \\
\text { (menyeb } \\
\text { ar) }\end{array}$ \\
\hline 19 & $\begin{array}{c}3 \\
\text { (sangat } \\
\text { sesuai }\end{array}$ & $\begin{array}{c}1 \\
\text { (Tidak } \\
\text { sesuai) }\end{array}$ & $\begin{array}{c}3 \\
\text { (Sangat } \\
\text { sesuai) }\end{array}$ & $\begin{array}{c}3 \\
\text { (Sangat } \\
\text { sesuai) }\end{array}$ & $\begin{array}{c}3 \\
\text { (Sangat } \\
\text { sesuai) }\end{array}$ & $\begin{array}{c}1 \\
\text { (Tidak sesuai) }\end{array}$ & $\begin{array}{c}3 \\
\text { (sangat sesuai) }\end{array}$ & $\begin{array}{c}2 \\
\text { (menyeb } \\
\text { ar) }\end{array}$ \\
\hline 20 & $\begin{array}{c}3 \\
\text { (sangat } \\
\text { sesuai }\end{array}$ & $\begin{array}{c}1 \\
\text { (Tidak } \\
\text { sesuai) } \\
\end{array}$ & $\begin{array}{c}3 \\
\text { (Sangat } \\
\text { sesuai) }\end{array}$ & $\begin{array}{c}3 \\
\text { (Sangat } \\
\text { sesuai) } \\
\end{array}$ & $\begin{array}{c}3 \\
\text { (Sangat } \\
\text { sesuai) }\end{array}$ & $\begin{array}{c}1 \\
\text { (Tidak sesuai) }\end{array}$ & $\begin{array}{c}3 \\
\text { (sangat sesuai) }\end{array}$ & $\begin{array}{c}2 \\
\text { (menyeb } \\
\text { ar) }\end{array}$ \\
\hline 21 & $\begin{array}{c}3 \\
\text { (sangat } \\
\text { sesuai }\end{array}$ & $\begin{array}{c}1 \\
\text { (Tidak } \\
\text { sesuai) } \\
\end{array}$ & $\begin{array}{c}3 \\
\text { (Sangat } \\
\text { sesuai) }\end{array}$ & $\begin{array}{c}3 \\
\text { (Sangat } \\
\text { sesuai) }\end{array}$ & $\begin{array}{c}3 \\
\text { (Sangat } \\
\text { sesuai) }\end{array}$ & $\begin{array}{c}1 \\
\text { (Tidak sesuai) }\end{array}$ & $\begin{array}{c}3 \\
\text { (sangat sesuai) }\end{array}$ & $\begin{array}{c}2 \\
\text { (menyeb } \\
\text { ar) }\end{array}$ \\
\hline
\end{tabular}




\begin{tabular}{|c|c|c|c|c|c|c|c|c|}
\hline 22 & $\begin{array}{c}3 \\
\text { (sangat } \\
\text { sesuai }\end{array}$ & $\begin{array}{c}1 \\
\text { (Tidak } \\
\text { sesuai) }\end{array}$ & $\begin{array}{c}3 \\
\text { (Sangat } \\
\text { sesuai) }\end{array}$ & $\begin{array}{c}3 \\
\text { (Sangat } \\
\text { sesuai) }\end{array}$ & $\begin{array}{c}3 \\
\text { (Sangat } \\
\text { sesuai) }\end{array}$ & $\begin{array}{c}1 \\
\text { (Tidak sesuai) }\end{array}$ & $\begin{array}{c}3 \\
\text { (sangat sesuai) }\end{array}$ & $\begin{array}{c}1 \\
\text { (memusa } \\
\mathrm{t})\end{array}$ \\
\hline 23 & $\begin{array}{c}3 \\
\text { (sangat } \\
\text { sesuai } \\
\end{array}$ & $\begin{array}{c}1 \\
\text { (Tidak } \\
\text { sesuai) }\end{array}$ & $\begin{array}{c}3 \\
\text { (Sangat } \\
\text { sesuai) }\end{array}$ & $\begin{array}{c}3 \\
\text { (Sangat } \\
\text { sesuai) }\end{array}$ & $\begin{array}{c}3 \\
\text { (Sangat } \\
\text { sesuai) }\end{array}$ & $\begin{array}{c}3 \\
\text { (Sangat sesuai) }\end{array}$ & $\begin{array}{c}3 \\
\text { (sangat sesuai) }\end{array}$ & $\begin{array}{c}2 \\
\text { (menyeb } \\
\text { ar) }\end{array}$ \\
\hline 24 & $\begin{array}{c}3 \\
\text { (sangat } \\
\text { sesuai }\end{array}$ & $\begin{array}{c}1 \\
\text { (Tidak } \\
\text { sesuai) }\end{array}$ & $\begin{array}{c}3 \\
\text { (Sangat } \\
\text { sesuai) }\end{array}$ & $\begin{array}{c}3 \\
\text { (Sangat } \\
\text { sesuai) }\end{array}$ & $\begin{array}{c}3 \\
\text { (Sangat } \\
\text { sesuai) }\end{array}$ & $\begin{array}{c}3 \\
\text { (Sangat sesuai) }\end{array}$ & $\begin{array}{c}3 \\
\text { (sangat sesuai) }\end{array}$ & $\begin{array}{c}2 \\
\text { (menyeb } \\
\text { ar) }\end{array}$ \\
\hline 25 & $\begin{array}{c}3 \\
\text { (sangat } \\
\text { sesuai } \\
\end{array}$ & $\begin{array}{c}1 \\
\text { (Tidak } \\
\text { sesuai) } \\
\end{array}$ & $\begin{array}{c}3 \\
\text { (Sangat } \\
\text { sesuai) } \\
\end{array}$ & $\begin{array}{c}3 \\
\text { (Sangat } \\
\text { sesuai) } \\
\end{array}$ & $\begin{array}{c}3 \\
\text { (Sangat } \\
\text { sesuai) } \\
\end{array}$ & $\begin{array}{c}3 \\
\text { (Sangat sesuai) }\end{array}$ & $\begin{array}{c}2 \\
\text { (sesuai) }\end{array}$ & $\begin{array}{c}2 \\
\text { (menyeb } \\
\text { ar) }\end{array}$ \\
\hline 26 & $\begin{array}{c}3 \\
\text { (sangat } \\
\text { sesuai } \\
\end{array}$ & $\begin{array}{c}1 \\
\text { (Tidak } \\
\text { sesuai) }\end{array}$ & $\begin{array}{c}3 \\
\text { (Sangat } \\
\text { sesuai) }\end{array}$ & $\begin{array}{c}3 \\
\text { (Sangat } \\
\text { sesuai) }\end{array}$ & $\begin{array}{c}3 \\
\text { (Sangat } \\
\text { sesuai) }\end{array}$ & $\begin{array}{c}3 \\
\text { (Sangat sesuai) }\end{array}$ & $\begin{array}{c}2 \\
\text { (sesuai) }\end{array}$ & $\begin{array}{c}2 \\
\text { (menyeb } \\
\text { ar) }\end{array}$ \\
\hline 27 & $\begin{array}{c}3 \\
\text { (sangat } \\
\text { sesuai }\end{array}$ & $\begin{array}{c}1 \\
\text { (Tidak } \\
\text { sesuai) }\end{array}$ & $\begin{array}{c}3 \\
\text { (Sangat } \\
\text { sesuai) }\end{array}$ & $\begin{array}{c}3 \\
\text { (Sangat } \\
\text { sesuai) }\end{array}$ & $\begin{array}{c}3 \\
\text { (Sangat } \\
\text { sesuai) }\end{array}$ & $\begin{array}{c}3 \\
\text { (Sangat sesuai) }\end{array}$ & $\begin{array}{c}2 \\
\text { (sesuai) }\end{array}$ & $\begin{array}{c}2 \\
\text { (menyeb } \\
\text { ar) }\end{array}$ \\
\hline 28 & $\begin{array}{c}3 \\
\text { (sangat } \\
\text { sesuai }\end{array}$ & $\begin{array}{c}1 \\
\text { (Tidak } \\
\text { sesuai) }\end{array}$ & $\begin{array}{c}3 \\
\text { (Sangat } \\
\text { sesuai) }\end{array}$ & $\begin{array}{c}3 \\
\text { (Sangat } \\
\text { sesuai) }\end{array}$ & $\begin{array}{c}3 \\
\text { (Sangat } \\
\text { sesuai) }\end{array}$ & $\begin{array}{c}3 \\
\text { (Sangat sesuai) }\end{array}$ & $\begin{array}{c}2 \\
\text { (sesuai) }\end{array}$ & $\begin{array}{c}1 \\
\text { (memusa } \\
\mathrm{t})\end{array}$ \\
\hline 29 & $\begin{array}{c}3 \\
\text { (sangat } \\
\text { sesuai } \\
\end{array}$ & $\begin{array}{c}1 \\
\text { (Tidak } \\
\text { sesuai) } \\
\end{array}$ & $\begin{array}{c}3 \\
\text { (Sangat } \\
\text { sesuai) } \\
\end{array}$ & $\begin{array}{c}3 \\
\text { (Sangat } \\
\text { sesuai) } \\
\end{array}$ & $\begin{array}{c}3 \\
\text { (Sangat } \\
\text { sesuai) } \\
\end{array}$ & $\begin{array}{c}3 \\
\text { (Sangat sesuai) }\end{array}$ & $\begin{array}{c}3 \\
\text { (sangat sesuai) }\end{array}$ & $\begin{array}{c}2 \\
\text { (menyeb } \\
\text { ar) }\end{array}$ \\
\hline 30 & $\begin{array}{c}3 \\
\text { (sangat } \\
\text { sesuai }\end{array}$ & $\begin{array}{c}1 \\
\text { (Tidak } \\
\text { sesuai) } \\
\end{array}$ & $\begin{array}{c}3 \\
\text { (Sangat } \\
\text { sesuai) } \\
\end{array}$ & $\begin{array}{c}3 \\
\text { (Sangat } \\
\text { sesuai) } \\
\end{array}$ & $\begin{array}{c}3 \\
\text { (Sangat } \\
\text { sesuai) }\end{array}$ & $\begin{array}{c}3 \\
\text { (Sangat sesuai) }\end{array}$ & $\begin{array}{c}3 \\
\text { (sangat sesuai) }\end{array}$ & $\begin{array}{c}2 \\
\text { (menyeb } \\
\text { ar) }\end{array}$ \\
\hline 31 & $\begin{array}{c}3 \\
\text { (sangat } \\
\text { sesuai } \\
\end{array}$ & $\begin{array}{c}1 \\
\text { (Tidak } \\
\text { sesuai) }\end{array}$ & $\begin{array}{c}3 \\
\text { (Sangat } \\
\text { sesuai) }\end{array}$ & $\begin{array}{c}2 \\
\text { (Sesuai) }\end{array}$ & $\begin{array}{c}3 \\
\text { (Sangat } \\
\text { sesuai) }\end{array}$ & $\begin{array}{c}2 \\
\text { (Sesuai) }\end{array}$ & $\begin{array}{c}3 \\
\text { (sangat sesuai) }\end{array}$ & $\begin{array}{c}2 \\
\text { (menyeb } \\
\text { ar) }\end{array}$ \\
\hline 32 & $\begin{array}{c}3 \\
\text { (sangat } \\
\text { sesuai }\end{array}$ & $\begin{array}{c}1 \\
\text { (Tidak } \\
\text { sesuai) }\end{array}$ & $\begin{array}{c}3 \\
\text { (Sangat } \\
\text { sesuai) }\end{array}$ & $\begin{array}{c}3 \\
\text { (Sangat } \\
\text { sesuai) }\end{array}$ & $\begin{array}{c}3 \\
\text { (Sangat } \\
\text { sesuai) }\end{array}$ & $\begin{array}{c}2 \\
\text { (Sesuai) }\end{array}$ & $\begin{array}{c}3 \\
\text { (sangat sesuai) }\end{array}$ & $\begin{array}{c}1 \\
\text { (memusa } \\
\mathrm{t})\end{array}$ \\
\hline 33 & $\begin{array}{c}3 \\
\text { (sangat } \\
\text { sesuai } \\
\end{array}$ & $\begin{array}{c}1 \\
\text { (Tidak } \\
\text { sesuai) }\end{array}$ & $\begin{array}{c}3 \\
\text { (Sangat } \\
\text { sesuai) }\end{array}$ & $\begin{array}{c}3 \\
\text { (Sangat } \\
\text { sesuai) } \\
\end{array}$ & $\begin{array}{c}3 \\
\text { (Sangat } \\
\text { sesuai) }\end{array}$ & $\begin{array}{c}2 \\
\text { (Sesuai) }\end{array}$ & $\begin{array}{c}3 \\
\text { (sangat sesuai) }\end{array}$ & $\begin{array}{c}2 \\
\text { (menyeb } \\
\text { ar) }\end{array}$ \\
\hline
\end{tabular}

Lampiran 2. Analisis Regresi Linear Berganda

\begin{tabular}{|l|r|r|r|r|r|}
\hline Model & Sum of Squares & df & Mean Square & F & Sig. \\
\hline 1 Regression & .279 & 5 & .056 & .616 & $.689^{\mathrm{a}}$ \\
Residual & 2.448 & 27 & .091 & & \\
Total & 2.727 & 32 & & & \\
\hline
\end{tabular}

a. Predictors: (Constant), topografi, hukum, pekerjaan, prasarana, aksesibilitas

b. Dependent Variable: pola

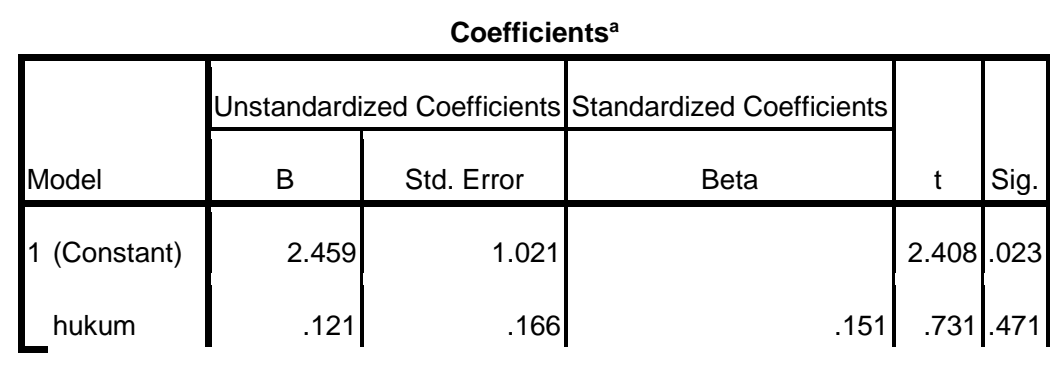




\begin{tabular}{|c|c|c|c|c|c|}
\hline \multicolumn{6}{|c|}{ Coefficients $^{a}$} \\
\hline \multirow[b]{2}{*}{ Model } & \multicolumn{2}{|c|}{ Unstandardized Coefficients } & \multirow{2}{*}{\begin{tabular}{|c|} 
Standardized Coefficients \\
Beta
\end{tabular}} & \multirow[b]{2}{*}{$\mathrm{t}$} & \multirow[b]{2}{*}{ Sig. } \\
\hline & B & Std. Error & & & \\
\hline prasarana & -.201 & .149 & -.330 & -1.350 & .188 \\
\hline aksesibilitas & .154 & .169 & .246 & .911 & .371 \\
\hline pekerjaan & -.177 & .240 & -.147 & -.739 & .466 \\
\hline topografi & -.018 & .089 & -.047 & -.197 & .845 \\
\hline
\end{tabular}

a. Dependent Variable: pola

Lampiran 3. Gambar Peta Zona Kawasan Permukiman

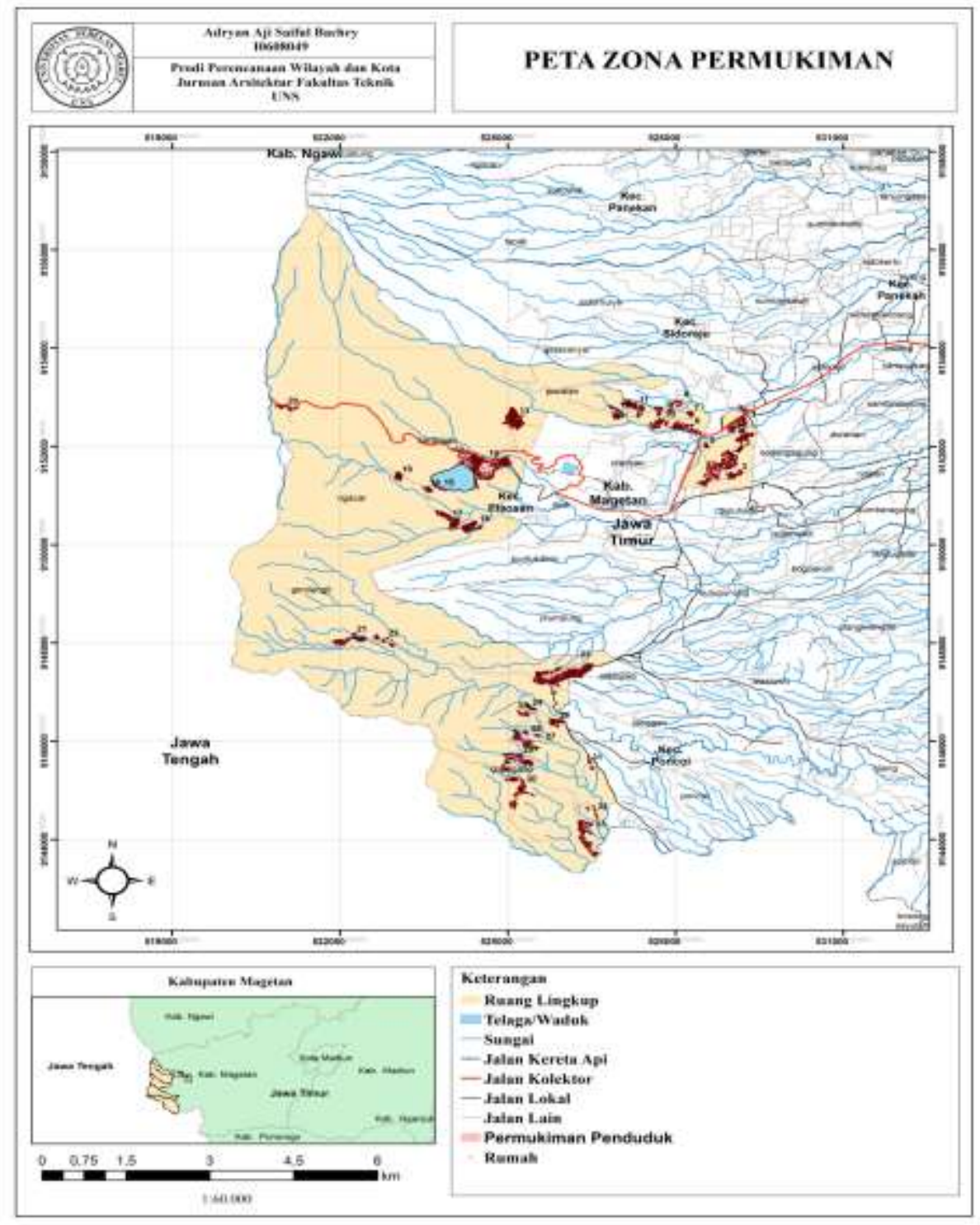

Sumber : BAPPEDA Kabupaten Magetan 